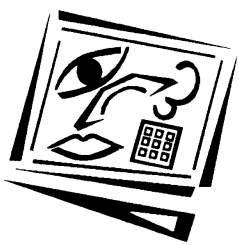

Australasian Journal of

Volume 27, Number 2, 2011

ISSN 1449-5554 (online)

\title{
Contents
}

Editorial 27(2)

iii-ix

Tertiary sector

Students' satisfaction and valuation of web-based lecture recording technologies

Ross H. Taplin, Lee Hun Low and Alistair M. Brown

$175-191$

A matched-pairs study of interactive computer laboratory activities

in a liberal arts math course

Frederick Butler and Melanie Butler

Design, sharing and co-construction of learning resources: A case of

lifelong learning communities in Shanghai

Xiaoqing Gu, Chongping Zha, Shusu Li and James M. Laffey

Factors influencing perceived usefulness of wikis for group collaborative

learning by first year students

Zixiu Guo and Kenneth John Stevens

Instructional design for cross-cultural online collaboration: Grouping

strategies and assignment design

Chun-Min Wang

ICT use by journalism professors in Colombia

Elías Said Hung

Evaluating computer-based simulations, multimedia and animations that

help integrate blended learning with lectures in first year statistics

David L. Neumann, Michelle M. Neumann and Michelle Hood

\section{Schools sector}

An information-summarising instruction strategy for improving the web-based problem-solving abilities of students

Gwo-Jen Hwang and Fan-Ray Kuo

Perceptions of interactive whiteboard pedagogy in the teaching of

Chinese language

Hui Ling Xu and Robyn Moloney

Digitalising our schools: Clarity and coherence in policy

Lorrae Ward and Judy M Parr

Factors leading to the adoption of a learning technology: The case of

graphics calculators

Boris Handal, Michael Cavanagh, Leigh Wood and Peter Petocz

Framing ICT implementation in a context of educational change:

A structural equation modelling analysis

Emily M. L. Wong and Sandy C. Li 
The Australasian Journal of Educational Technology (AJET) is a refereed research journal published 6 times per year by the Australasian Society for Computers in Learning in Tertiary Education (ascilite). AJET retired its printed version (ISSN 1449-3098) at the end of Volume 23, 2007, and from Volume 24, 2008, the journal is open access, online only (ISSN 1449-5554), and does not have paid subscriptions.

(C) 2011 Authors retain copyright in their individual articles, whilst copyright in AJET as a compilation is retained by the publisher. Except for authors reproducing their own articles, no part of this journal may be reprinted or reproduced without permission. For further details, and for details on submission of manuscripts and open access to all issues of AJET published since the journal's foundation in 1985, please see http:/ / www.ascilite.org.au/ajet/

For editorial inquiries, contact the Editor, Associate Professor Catherine McLoughlin, School of Education (ACT), Australian Catholic University, PO Box 256, Dickson ACT 2602, Australia. Email: Catherine.McLoughlin@acu.edu.au, Tel: +61262091100 Fax +61262091185.

For review process, production, website and business matters, contact the Production Editor, Dr Roger Atkinson, 5/ 202 Coode Street, Como WA 6152, Australia. Email: rjatkinson@bigpond.com, Tel: +61 89367 1133. Desktop publishing (PDF versions) and HTML by Roger Atkinson.

AJET is managed by a Committee comprising ASCILITE Executive nominees, the convenors or nominees from previous ascilite Conferences, and AJET's previous editors and current senior editorial staff. The 2010 Management Committee members are:

Professor Mike Keppell, Charles Sturt University, ASCILITE President

Dr Philippa Gerbic, Auckland University of Technology, ASCILITE Executive

Professor Geoffrey Crisp, University of Adelaide, ASCILITE 2003 Convenor

Dr Rob Phillips, Murdoch University, ASCILITE 2004 Convenor

Professor Peter Goodyear, University of Sydney, ASCILITE 2006 Convenor

Dr Dale Holt, Deakin University, ASCILITE 2008 Convenor

Professor Ron Oliver, Edith Cowan University, AJET Editor 1997-2001

Assoc Prof Catherine McLoughlin (Editor), Australian Catholic University

Dr Roger Atkinson (Production Editor)

AJET's Editorial Board (see http://www.ascilite.org.au/ajet/about/editorialboard.html) reflects the journal's commitment to academic excellence in educational technology and related areas of research and professional practice, our vision of an international journal with an Australasian regional emphasis, and our origins as a professional and learned society publication. 


\section{Editorial 27(2)}

\section{AJET's Special Issue program}

AJET's inaugural Special Issue, Interactive whiteboards: An Australasian perspective, appeared in Volume 26, 2010 [1]. In Volume 27, 2011 we will present Assessing students' Web 2.0 activities in higher education [2], and in Volume 28, 2012 we return to the Australasian region theme with Virtual worlds in tertiary education: An Australasian perspective [3]. Negotiations are at advanced stage for the next two special issues, the first with provisional scheduling at end 2011 for ICT for accessible, effective and efficient higher education: Experiences of Southeast Asia, edited by Associate Professor Kian-Sam Hong (Universiti Malaysia Sarawak) and Professor Kwok-Wing Lai (University of Otago, NZ). The second is Building the capacity of the next generation of teachers in Asia, edited by Professor Cher Ping Lim (Hong Kong Institute of Education) and Dr Ching Sing Chai (National Institute of Education, Nanyang Technological University, Singapore), provisionally scheduled for mid-2012, with details to be announced later in June 2011.

We are pleased to announce that another Special Issue has been added to AJET Volume 26(8), 2010. This is Learning technology and organisations: Transformational impact? edited by Professor Martin Hall (University of Salford, UK) Professor Mike Keppell (Charles Sturt University) and Professor John Bourne (The Sloan Consortium, USA) [4]. From a publishing perspective, this is a notable Special Issue as it is based upon an international collaboration between the UK's Association for Learning Technology, ascilite, and the USA's Sloan Consortium, intended to draw its articles more widely to the attention of the members of the three societies and organisations identified with the three editors, in ascilite's case via Professor Mike Keppell and AJET, and in Sloan-C's case, via Journal of Asynchronous Learning Networks [5]. As the definitive date of publication is 2010, set in ALT's Research in Learning Technology [6], the links to the Special Issue articles appear in AJET's Volume 26, 2010 [4].

In developing a strategy and AJET's Guidelines for special issues [7], we have taken note of the practices adopted by a 'peer group' of journals (Table 1). There is wide variation in special issue frequency, regularity and positioning (i.e. whole of issue or special section within an otherwise regular issue). For example, AJET is a relatively late entrant into special issues; some journals have had an 'on-off' or 'in-out' aproach to special issues; and use of 'mixed issues' that include 'special sections' is common, or even invariable as is the case with ET\&S. There is some variation in the concept of a special issue, for example some of C\&E's specials are based upon a selection of papers

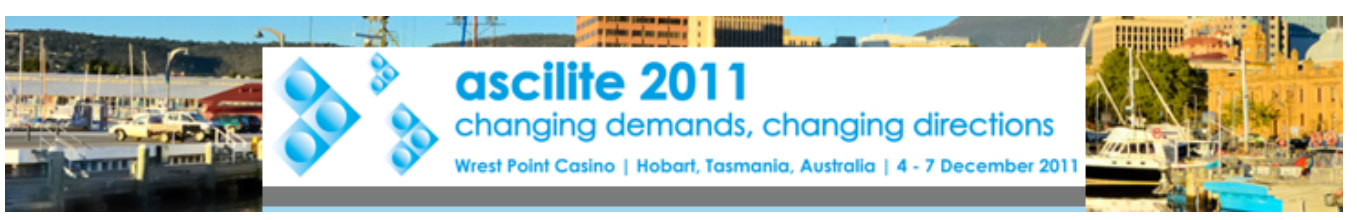

Hobart, 4-7 December 2011. http://www.ascilite.org.au/conferences/hobart11/ 


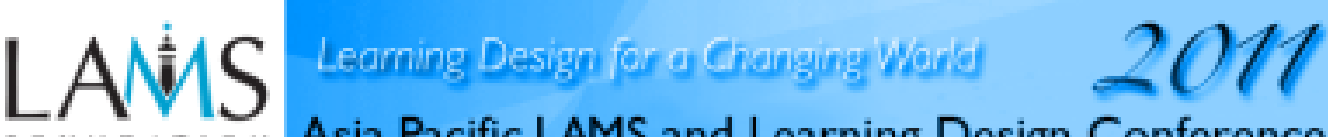 LOU ADAT IO N Asia Pacific LAMS and Learning Design Conference}

Nanyang Technological University, Singapore, 6-7 June 2011. http:/lams2011.lamsfoundation.org/

from a recent conference. In some instances it is difficult for the reader to ascertain whether an issue is "special" or otherwise, as the accompanying editorial may not be explicit about the purposes and justifications for the special issue. However, one justification that may be inferred, though not identified explicitly, is that special issues give the journal's editorial staff a bit of a rest. A guest editor or editors look after publicity, invitations, review processes, author liaison, acceptance and rejection advice, and some or much of the substantive editing and copy editing requirements. That is very much appreciated, and though we cannot speak for editors of other journals, authors and readers, very likely this appreciation is universal.

Table 1: Numbers of special issues by some educational technology journals, 2006-11

\begin{tabular}{|c|c|c|c|c|c|c|c|c|c|c|c|c|}
\hline \multirow{2}{*}{$\begin{array}{l}\text { Journal } \\
\text { (c) }\end{array}$} & \multicolumn{2}{|c|}{2006} & \multicolumn{2}{|c|}{2007} & \multicolumn{2}{|c|}{2008} & \multicolumn{2}{|c|}{2009} & \multicolumn{2}{|c|}{2010} & \multicolumn{2}{|c|}{ 2011(a) } \\
\hline & Spec & Total & Spec & Total & Spec & Total & Spec & Total & Spec & Total & Spec & Total \\
\hline AJET & 0 & 4 & 0 & 4 & 0 & 5 & 0 & 5 & 1 & 7 & 2 & 8 \\
\hline BJET & 2 & 6 & 2 & 6 & 1 & 6 & 2 & 6 & 3 & 6 & 0 & 6 \\
\hline $\mathrm{C} \& \mathrm{E}$ & 2 & 8 & 1 & 8 & 1 & 8 & 1(b) & 8 & 1 & 8 & 1(b) & 8 \\
\hline ETR\&D & 0 & 6 & 0 & 6 & 1 & 5 & 1 & 6 & 0 & 6 & & 6 \\
\hline JCAL & 1 & 6 & 2(b) & 6 & 1(b) & 6 & 1 & 6 & 4(b) & 6 & & 6 \\
\hline ET\&S & 4(b) & 4 & 4(b) & 4 & 1(b) & 4 & $3(b)$ & 4 & 3(b) & 4 & 1(b) & 4 \\
\hline ALT-J & 0 & 3 & 0 & 3 & 1 & 3 & 1 & 3 & 1 & 3 & & 3 \\
\hline JALN & 1 & 4 & 1 & 4 & 2 & 3 & 0 & 4 & 0 & 4 & 1 & 4 \\
\hline
\end{tabular}

Notes

a. 2011 data are estimates for the full year, or counts to 15 April 2011, or in the case of empty cells, no estimate is reasonably possible.

b. The count of special issues includes one or more instances of "special sections" leading an otherwise regular issue.

c. For journal details refer to the websites:

AJET Australasian Journal of Educational Technology. http:/ / www.ascilite.org.au/ajet/

BJET British Journal of Educational Technology.

http:/ / onlinelibrary.wiley.com/journal/10.1111/(ISSN)1467-8535

C\&E Computers \& Education.

http:/ / www.elsevier.com/wps / find / journaldescription.cws_home/347/description

ETR\&D Educational Technology Research and Development. http: / / www.springerlink.com/ content/119965 /

JCAL Journal of Computer Assisted Learning.

http: / / www.wiley.com / bw / journal.asp? ref=0266-4909\&site=1

ET\&S Educational Technology \& Society. http:/ / www.ifets.info/

ALT-J now Research in Learning Technology.

http: / / www.informaworld.com / smpp / title db=all content=t713605628

JALN Journal of Asynchronous Learning Networks.

http: / / sloanconsortium.org/publications/jaln_main 


\section{Educational sector representation in educational technology journals}

This topic continues investigations into a matter flagged in Editorial 26(7) [8] for further investigation. We noted that:

Feedback to date has concentrated on one aspect of the secondary question, "Or will AJET's fortunes be better progressed as a more specialised journal, for example tertiary education only?" Twelve of the fifteen responses to date singled out "tertiary education

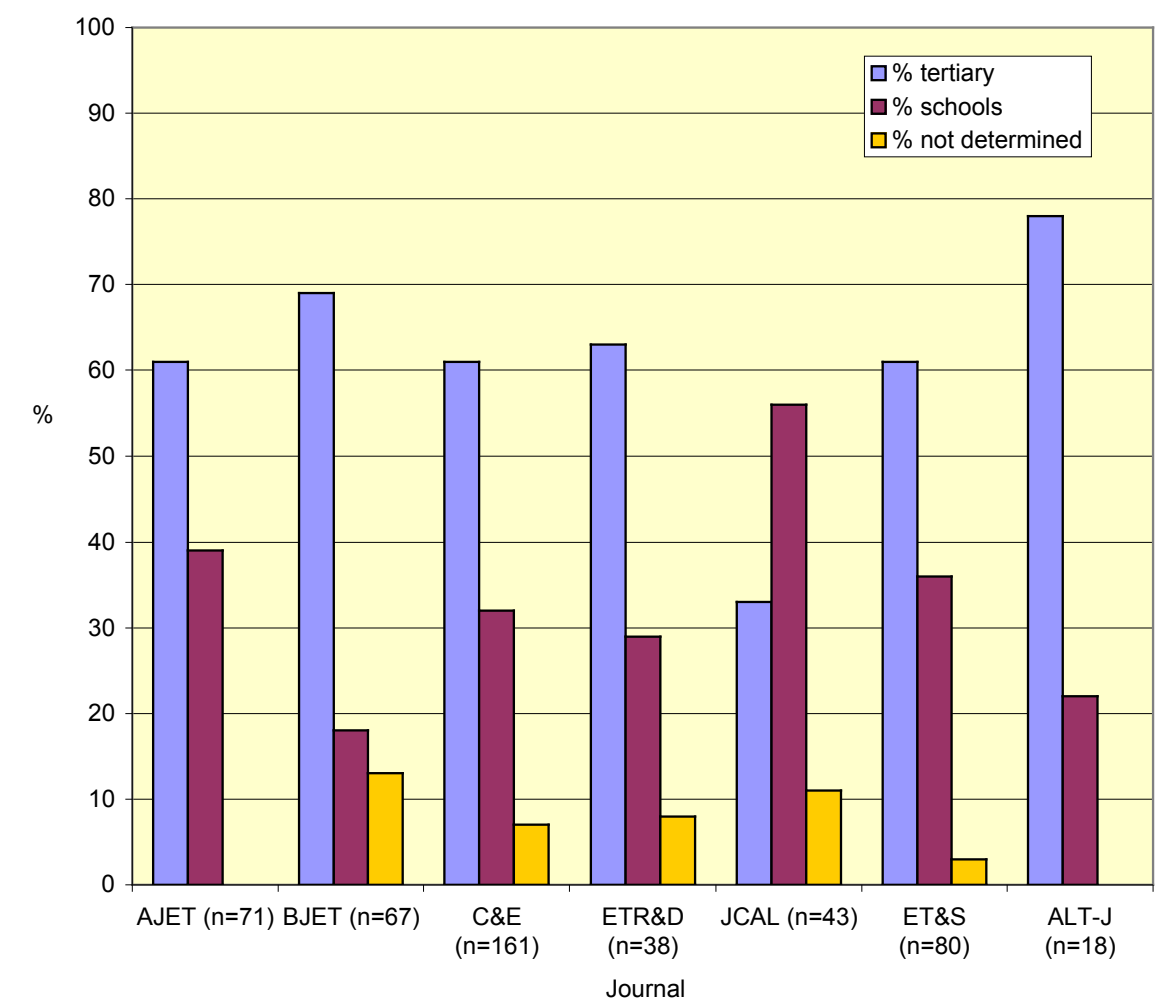

Figure 1: Educational sector representation in some of educational technology's major journals, 2010

\section{Notes}

1. Counts were made for all regular articles (excluding editorials colloquia and reviews) for all issues of the journal in 2010 (except for C\&E, which was counted only for Vol 55, Aug-Dec).

2. Classifications into "tertiary" and "schools" sectors were based on the research context and the ages and locations of the observed subjects or groups, not on the nature of the technologies discussed or the institutional affiliations of the researchers. The category "not determined" counts articles for which category was not clear from context (as described in the abstract), or articles that are classifiable as relevant for both sectors. Different observers may obtain slightly different counts (this count by RA only).

3. See Notes accompanying Table 1 for journal identifications and home pages.

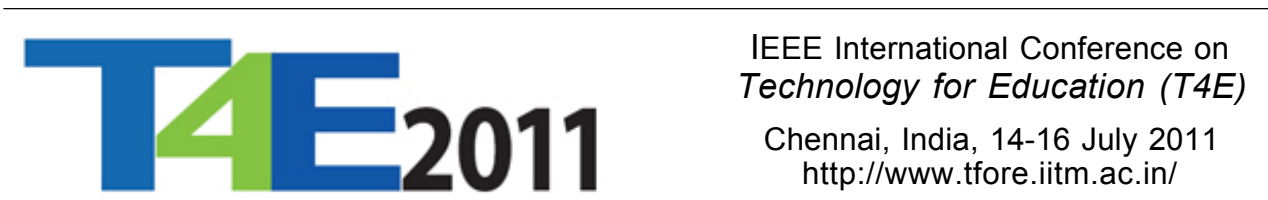


only" as the most appropriate direction to take. What we will need to do, after outcomes from the current Tiers Review are known (thus giving a better indication of what really is important), and prior to AJET Management Committee's consideration, is undertake some further research into how AJET compares with "similar international journals". [8]

Figure 1 provides the first item of further research into the practices of similar international journals. To place it into the all important feature of the current context, the listed journals are ranked Tier A (BJET, C\&E, ETR\&D, JCAL and ALT-J) or Tier B (AJET, ET\&S) [9], [10]. The proportions classified as "schools" range from modest (BJET, ALT-J) to significant (AJET, C\&E, ETR\&D, ET\&S) or in one case, near predominant (JCAL). In the Tiers context, and assuming that the current norms (5\% $\mathrm{A}^{*}, 15 \% \mathrm{~A}, 30 \% \mathrm{~B}$ and $50 \% \mathrm{C}$ ) remain unchanged by the review now in progress [11], can we see any way for a change of "sector coverage" to advantage AJET relative to BJET, C\&E, ETR\&D, JCAL and ALT-J - one of which has to be demoted if AJET is to regain a Tier $A$ ranking?

Certainly we will need further research, which very necessarily will require the gleaning of information from the current review's outcomes. From the outcomes we may obtain better insights into "what does it take?" to obtain promotion to a higher tier. The problem of understanding the basis for the 2010 Tier rankings was a theme picked up in several of the Editorial Board Member responses, for example:

\begin{abstract}
A strategy for becoming a top 5, Tier A journal might include trying to gain a clear understanding of ranking criteria and developing the journal in alignment with the criteria. I believe that a lot of work has been done around trying to understand the ranking criteria but am not sure right now of the outcome, i.e. are we now clear about what we would need to achieve to gain an A ranking? Also, I wonder what benchmarking against current top 5, A rated journals would reveal. [12]
\end{abstract}

On the matter of "benchmarking against the current top 5", we reported upon that in AJET Editorial 26(5) [9]. However, "a clear understanding of ranking criteria" is a more elusive goal. In their discussion, Editorial Board members touched upon several matters, including an apprehension that "our 'B' ERA rating might be due to a view that non-commercial publishers are seen as second rate"; Board composition: "the more people you have on the Editorial Board with the Professorial title and the more well-known they are, the better the chance of the A ranking"; frequency of issues: "strive to get more issues to be published yearly. The current Tier $\mathrm{A}^{*}$ journals seem to have more issues than the rest" (see Figure 1 for a small sample); "the ranking depends on lobbying" [8]; and "the citation index".

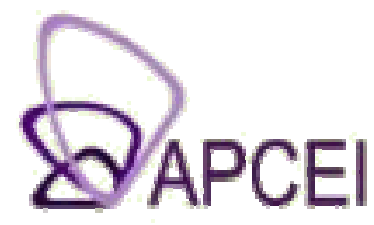

5th Asia Pacific Conference on Educational Integrity

The University of Western Australia

Perth, 26-28 September 2011

http://www.catl.uwa.edu.au/5apcei 


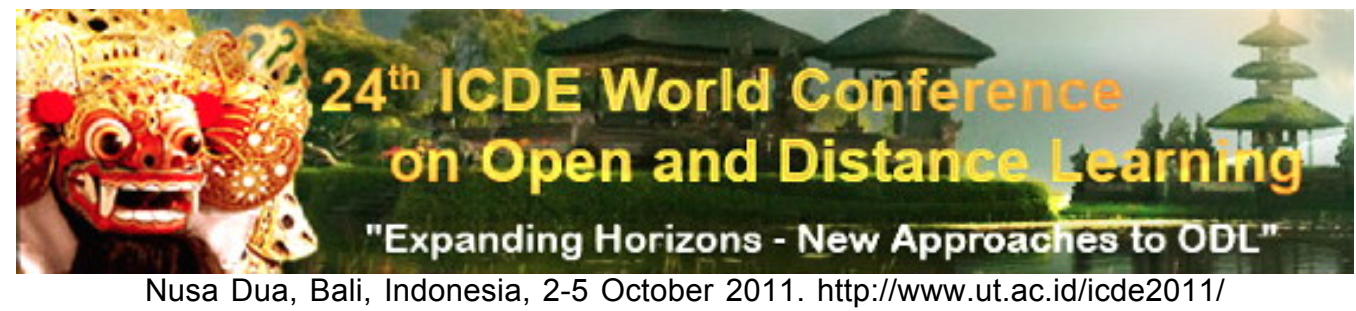

Nusa Dua, Bali, Indonesia, 2-5 October 2011. http://www.ut.ac.id/icde2011/

How will the Tier Review outcomes enable our insights into "what does it take?" to be improved? It is reasonable to predict that there will be very little information published about the recommendations made by the contracted "peak bodies", the evidence that they considered, how they obtained their rankings, and the extent to which the ARC accepted or modified those recommendations. That expectation is based upon the changes we have noted between Tiers 2008 and Tiers 2010 [13], and the dearth of information about the basis for the changes [14, 15]. The ARC is "outcomes focused" and may be inclined to discourage the emergence of evidence or records that may facilitate challenges to the stature of Tiers 2012. So, researchers into these matters may have to use a "reverse engineering" approach, that is compile lists of promotions and demotions for particular groups of journals or specific Fields of Research [10] and from these try to deduce any principles or specific data that may have been used. The Wikipedia definition of "reverse engineering" contains some pertinent phrases [16]:

Reverse engineering has its origins in the analysis of hardware for commercial or military advantage. The purpose is to deduce design decisions from end products with little or no additional knowledge about the procedures involved in the original production. The same techniques are subsequently being researched for application to legacy software systems, not for industrial or defence ends, but rather to replace incorrect, incomplete, or otherwise unavailable documentation. [16]

The Tier Review outcomes for educational technology journals may have a specific impact upon the question of educational sector representation within AJET. If we find that educational research journals concerned mainly with tertiary sector topics do well in the Tiers Review (e.g. more promotions than demotions) compared with those concerned mainly with schools sector topics, then of course AJET will be under pressure to migrate in the direction of "more tertiary", whilst our prospective authors will be under pressure to move in the same direction in order to have a better chance of scoring an $\mathrm{A}^{*} / \mathrm{A}$ ranked paper. Conversely, if journals concerned mainly with schools sector topics... clearly there is a strange paradox here. Will research priorities suffer a distortion as researchers become over-concerned about "adjusting" their work to suit an $A^{*} / \mathrm{A}$ journal that is not especially appropriate for it? What

Fifth Joint Conference of APACALL and PacCALL
Do local
Manila, Philippines
$27-29$ October 2011
http://glocall.org/


if such "adjusting" turns out to be inappropriate from an academic research perspective, from a community perspective, or from the perspectives of Government priorities?

It is a paradox, because normally one would expect Governments to opt for more direct influences over the research that is undertaken with Government funds, for example selection of topics and locations of research centres, in contrast to the more diffuse influence that seems to be associated with the ERA agenda. The next big emerging topic for research into research management and leadership policies may be the topic of tensions between the "rewarding of excellence", and the "rewarding of research that aligns well with academic, community and Government priorities".

\section{Educational sector representation in AJET: Article viewings counts}

An important question that very many editors worry about (though rarely write about) is whether the journal is doing well in selecting articles that will attain high citation counts (and declining articles that may attain only low citation counts). Naturally this is a difficult topic, because correlations between citation counts and academic merit may be poor, and of course academic merit is not easily rated and ranked. We have little prepared to date on citation counts for AJET articles, but a simple indication may be obtained from data on article viewing counts (page access counts or 'hit counts'). Table 2 presents a brief investigation.

Table 2: Viewing counts for AJET 26 articles

\begin{tabular}{|c|c|c|c|c|c|c|}
\hline \multirow{2}{*}{$\begin{array}{l}\text { AJET } \\
\text { issue }\end{array}$} & \multicolumn{3}{|c|}{ Tertiary } & \multicolumn{3}{|c|}{ Schools } \\
\hline & Count & No. artics & Mean & Count & No. artics & Mean \\
\hline $26(1)$ & 4293 & 9 & 477 & 485 & 1 & 485 \\
\hline $26(2)$ & 4337 & 8 & 542 & 689 & 2 & 345 \\
\hline $26(3)$ & 1744 & 4 & 436 & 4821 & 4 & 1205 \\
\hline $26(4)$ & 1559 & 3 & 520 & 2556 & 7 & 365 \\
\hline $26(5)$ & 1184 & 3 & 395 & 2368 & 6 & 395 \\
\hline $26(6)$ & 3691 & 9 & 410 & 1644 & 3 & 548 \\
\hline $26(7)$ & 1488 & 8 & 186 & 845 & 4 & 211 \\
\hline 26 totals & 18296 & 44 & 416 & 13408 & 27 & 497 \\
\hline
\end{tabular}

Of course only a very small proportion of article viewings will lead to a citation by another author, and this proportion may vary widely. A part of the count is due to search 'bots' collecting articles. Therefore the data in Table 2 has to be regarded cautiously, but it does suggest that the differences between "tertiary" and "schools" in viewing counts are minor, if anything "schools" articles may attract more viewing. It is probably reasonable to suggest that there is likely to be no major difference between citation counts for "tertiary" and "schools", that is, both categories will contribute more or less equally, on average, to citation count based bibliometrics such as the Thomson Reuters Impact Factor. As noted in Editorial 26(5) [9], AJET fared quite well with its first Impact Factor, namely 1.278 in 2010.

Roger Atkinson and Catherine McLoughlin AJET Production Editor and AJET Editor 


\section{0th Biennial Conference}

\section{Forging New Directions in Academic Language and Learning}

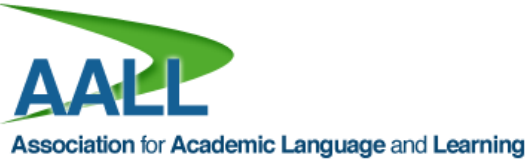

Adelaide, 24-25 November 2011. http://www.adelaide.edu.au/clpd/aall2011/

\section{Endnotes}

1. Thomas, M. \& Jones, A. (2010). Editorial 26(4): Preface to the Special issue. In M. Thomas \& A. Jones (Eds), Interactive whiteboards: An Australasian perspective. Australasian Journal of Educational Technology, 26(Special issue, 4), iii-vi.

http:/ / www.ascilite.org.au/ajet/ajet26/editorial26-4.html

2. http:/ / www.ascilite.org.au / ajet/about/ special-issues/assess-students-web2-2011.html

3. http: / / www .ascilite.org.au/ajet/about/ special-issues / virtual-worlds-2012.html

4. AJET 26(8). http://www.ascilite.org.au/ajet/ajet26/ajet26.html

5. http://sloanconsortium.org/publications/jaln_main

6. Hall, M., Keppell, M. \& Bourne, J. (2010). Learning technology and organisations:

Transformational impact? Research in Learning Technology, 18(3), 161-164.

http: / / dx.doi.org/10.1080/09687769.2010.529314 (local copy at

http:/ / www.ascilite.org.au/ajet/ajet26/ editorial26-8.pdf)

7. AJET. Guidelines for special issues. http://www.ascilite.org.au/ajet/about/specialissues/guidelines.html

8. AJET Editorial 27(1). AJET Editorial Board: Annual feedback sought. http: / / www.ascilite.org.au/ajet/ ajet27/ editorial27-1.html

9. AJET Editorial 26(5). Idle Moment 40: Impact Factor revisited. http: / / www.ascilite.org.au/ajet/ ajet26/ editorial26-5.html

10. For efficient access to Tiers and FoR data, we use Lamp, J. (2010). ERA Current Rankings Access. http:/ / lamp.infosys.deakin.edu.au/era/

11. ARC. Review of the ERA 2010 Ranked Outlet Lists. http:/ / www.arc.gov.au/era/era_2012/review_of_era10_ranked_outlet_lists.htm

12. Email to AJET Editorial Board from Dr Iain Doherty, 22 Dec 2010.

13. AJET Editorial 26(1). Journal rankings: AJET demoted. http: / / www.ascilite.org.au/ajet/ajet26/editorial26-1.html

14. Atkinson, R. J. (2010). ARC announces a Tier Review Process. HERDSA News, 32(3). http:/ / www.roger-atkinson.id.au/pubs/herdsa-news/32-3.html

15. Atkinson, R. J. (2011). Technology and control of feedback: My encounters with ROCI. HERDSA News, 33(1). http: / / www.roger-atkinson.id.au/pubs/herdsa-news/33-1.html

16. Wikipedia. Reverse engineering [viewed 18 Apr 2011] http:/ / en.wikipedia.org/wiki/Reverse_engineering

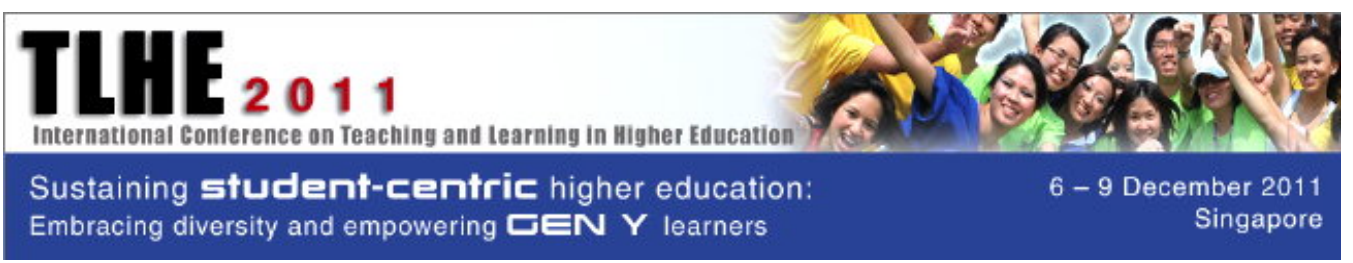

Singapore, 6-9 December 2011. http://www.cdtl.nus.edu.sg/tlhe/ 